\title{
Incorrect condom programming in the primary health care setting: "A prescription for a disaster"?
}

\author{
M de Wet, Lecturer, Department of Sociology, UFS \\ L Ackermann, Lecturer, Department of Sociology, UFS \\ A Crichton, Researcher, Department of Nursing, UFS
}

\section{Abstract}

In the effort to stem the HIV pandemic, the promotion of the correct and consistent use of condoms has to be a priority in the primary health care sector. This study, concentrating on the southern Free State, sought to identify obstacles to condom usage and to develop strategies to encourage condom usage. Both primary health care workers and their clients served as respondents in the study.

The findings of this study indicate that the following aspects related to primary health care do not pose serious obstacles to clients' attempts to obtain condoms: proximity of clinics, staff attitudes and the behaviour of staff towards clients. However, it does appear that primary health care workers neglect the counseling aspect of condom distribution, a vital aspect considering the importance of consistent and correct condom usage. Although various factors may contribute to this problem, the findings of this study indicate that the workload of staff is the most significant contributing factor.

Regarding clients, the biggest problem related to condom use revealed in this study, is the significant percentage of clients that do not use condoms correctly and consistently. The authors recommend that client education should be made a priority and that a person should be appointed specifically to ensure that counseling programs are implemented. This person does not necessarily have to be a highly qualified primary health care worker, but someone who speaks and understands the clients" "language" (in a broad cultural sense). The possibility of co-operation with non-government organisations should also be investigated.

\section{Introduction}

The importance of the use of condoms has increased in the light of the current HIV pandemic facing South Africa. Con-

\section{Opsomming}

In die poging om die HIV pandemie te kortwiek moet die bevordering van korrekte en konsekwente gebruik van kondome 'n prioriteit wees in die primêre gesondheidsorgsektor. Hierdie studie, wat op die SuidVrystaat konsentreer, poog om versperrings tot kondoomgebruik te identifiseer en om strategieë te ontwikkel om kondoomgebruik aan te moedig. Beide primêre gesondheidsorgwerkers en hul kliënte het as respondente in hierdie studie gedien.

Die bevindinge van hierdie studie toon aan dat die volgende aspekte van primêre gesondheidsorg nie ernstige probleme skep vir kliënte wat kondome wil bekom nie: afstand vanaf klinieke en die houding en die gedrag van personeel teenoor die kliënt. Dit wil egter voorkom asof primêre gesondheidsorgwerkers die voorligtingsaspek van kondoomverspreiding verwaarloos - 'n belangrike aspek gegewe die belang van die konsekwente en die korrekte gebruik van kondome. Alhoewel verskillende faktore mag bydra tot die probleem wil dit voorkom asof die werkslading van die personeel die belangrikste bydraende faktor is.

Betreffende die kliënte, toon hierdie studie aan dat die grootste versperring tot effektiewe kondoomgebruik die beduidende persentasie van kliënte is wat die kondome nie korrek en konsekwent gebruik nie. Die outeurs beveel aan dat kliëntevoorligting as ' $n$ prioriteit gestel moet word en dat 'n persoon aangestel moet word wat spesifiek verantwoordelikheid moet aanvaar vir die implementering van voorligtingsprogramme. Die persoon hoef nie noodwendig ' $n$ hoogs gekwalifiseerde gesondheidsorgwerker te wees nie, maar moet iemand wees wat die "taal" (in " $n$ breë kultuurverband) praat en verstaan. Die moontlikheid van samewerking met nie-regeringsorganisasies moet ook ondersoek word. 
doms are not used correctly and consistently (Warren, 1997; Sankar \& Karim, 1999; Pesa, Syre \& Fu, 1999).

In South Africa, condoms are available at Primary Health Care (PHC) clinics and are therefore available to the majority of South Africans. However, it is important to realise that availability does not necessarily lead to the use or the effective use of condoms for that matter. The South African Demographic and Health Survey conducted in 1998 found that only $22 \%$ of women aged 15-49 who had sexual intercourse in the 12 months preceding the survey, had ever used condom. Looking at the total figure, just under $80 \%$ of sexually active South African women are not practicing safe-sex (Department of Health, 1998:17). Only a third of teenagers were protecting themselves, the other two thirds were having unprotected sex. It is therefore crucial to investigate what barriers exist in the PHC setting that prevent the correct and consistent use of condoms and what attitudes or behaviour of the clients themselves may pose a barrier to the use of condoms.

\section{Setting}

The study concentrated on Region B of the Free State Province. This region consists of widely scattered small towns. Fifty three percent of the population in this area is rural. Region $\mathrm{B}$ is also considered to be economically poor with a monthly per capita income of R892 (Health Systems Trust and Department of Health, 1996:22). The nearest large urban centre is Bloemfontein (situated in Region A) where tertiary public health care facilities are available at Pelonomi, National and Universitas hospitals.

\section{Problem statement}

South Africa, like many other African countries, has a high rate of sexually transmitted diseases (STIs). It has been estimated that one quarter of South Africa's sexually active population may have at least one STI (Key, De Noon \& Boyles, 1997: 12). In Region B, primary health care workers (PHC workers) reported an exceptionally high incidence of STIs among their clients. Some PHC-workers reported treating as many as fourty clients per week for STIs.

One of the strategies to prevent STIs, HIV in particular, is the correct and consistent use of condoms. However, condoms are not always used effectively and consistently (Joffe, 1993: 701). It is important that the specific attitudes, knowledge and behavioural patterns related to condoms and condom use should be studied and understood in order to plan effective condom usage campaigns. In this regard researchers in Region $\mathrm{B}$ decided to launch a study focusing on condom usage.

\section{Methodology}

The research presented in this article formed part of the Primary Health Care Info Project which is part of an overall strategy in the Free State to develop an effective information system intended to guide primary health care policy planning and formulation, and the management thereof. The objective of the Info-project was to establish a research culture and capacity among PHC workers and related professions in the Free State. A multi-disciplinary approach was followed in this project, where primary health care workers participated in a research methodology-training program in order to develop research skills. They were selected in such as way as to be representative of the PHC clinics in the region. The Deutsche Gesellschaft fur Technische Zusammenarbeit (GTZ), the Health Systems Trust, and the Free State Department of Health sponsored the project. The project was implemented and co-ordinated by the Centre for Health Systems Research and Development of the University of the Free State.

Both quantitative and qualitative methods of data collection were employed during this study. Qualitative data was collected by means of a focus group. The focus group consisted of the PHC workers that participated in the above-mentioned training program and centred on the problems related to the provision of condoms to clients and the use of condoms by the clients, as a means of preventing STIs. This focus group served a dual purpose, as apart from collecting the relevant information, PHC-workers were also exposed to focus group facilitation techniques.

A questionnaire was designed and used to collect quantitative data from clients visiting the PHC clinics. For the survey, the unit of analysis was the patient who reported to the primary health care clinic for treatment of a sexually transmitted infection, as well as those who visited the clinic to obtain condoms. In this way the target population (sexually active clients) was reached. Focus groups were not used in this instance due to the sensitive nature of the topic, notwithstanding the logistic difficulties of conducting a focus group.

As a result of the sensitive nature and difficulties associated with researching this issue, a convenience sample was selected. It must therefore be borne in mind that the data, due to the convenient nature of the sample, cannot simply be used to make inferences to the population. However, even though the information is not generalisable, it may contribute to the understanding of condom usage and could thus be valuable to the design of condom distribution programmes.

Each of the clinics in Region B received twenty questionnaires. Ten questionnaires had to be completed with clients who visited the clinics for the treatment of sexually transmitted infections. The remaining ten questionnaires had to be completed with clients visiting the clinic for free condoms. The professional nurses at the various primary health care clinics acted as interviewers.

The nature of the questions in the interview was consistent with the general assessment and historical outline which, as a rule, has to be completed with the client who presents with a STI. The questionnaire consisted of three parts. Part I, focussed on service delivery and contained questions related to geographical accessibility, clinic hours, cost to reach the clinic and aspects related to service delivery (eg: "Do you trust the staff?'). Part ii, was related to sexual behaviour and condom usage and was introduced as follows: "The following questions are of a more personal nature and are related to sexual 
practices and habits. The researchers will appreciate if you answer the questions honestly, but please remember that you are answering these questions voluntarily and that you are under no obligation to answer questions that you do not want to answer". Part iii, collected biographical information as portrayed in table 1 . In an effort to ensure reliability and validity, the questionnaire was critically evaluated and scrutinised by research methodologists and experts in the field of condom research who were affiliated to the Centre for Health Systems Research and Development. It was also thoroughly analised and criticised by the researchers involved in the training program (PHC workers).

The qualitative data was analysed using a thematic approach where themes were identified from the transcriptions. The quantitative data was analysed using the SPSS statistical analysis programme.

Since the study involved the collection of sensitive information. careful attention was paid to ethical aspects. Neither the respondent's name, nor town was indicated on the questionnaire. All information was handled as highly confidential and the information was collected by professional nurses only, who are bound to a code of professional ethics which stipulates the confidential handling of all information entrusted to them in the course of their duties.

The client was fully informed about the nature of the study and the information that was required. It was emphasised that their participation was strictly voluntary and that they were free to withdraw from the interview at any stage. Clients were thus

\section{Table 1: Profile of respondents}

\begin{tabular}{|l|l|}
\hline Income-category & \\
\hline No income (leamers) & $25 \%$ \\
\hline No income (Unemployed) & $26.8 \%$ \\
\hline R0-RI00 & $1.8 \%$ \\
\hline RI0I-R500 & $30.4 \%$ \\
\hline R501-R1000 & $1.8 \%$ \\
\hline$>$ R1000 & $14.3 \%$ \\
\hline & \\
\hline Sex & \\
\hline Male & $61.4 \%$ \\
\hline Female & $38.6 \%$ \\
\hline & \\
\hline Marital status & \\
\hline Legally married & $13.2 \%$ \\
\hline Traditional marriage & $1.5 \%$ \\
\hline Cohabiting & $17.6 \%$ \\
\hline Single & $67.6 \%$ \\
\hline & \\
\hline Home Langauge & \\
\hline Sesotho & $43.8 \%$ \\
\hline IsiXhosa & $20.3 \%$ \\
\hline Sestwana & $4.7 \%$ \\
\hline Afrikaans & $31.3 \%$ \\
\hline & \\
\hline Age & \\
\hline $15-20$ & $20.9 \%$ \\
\hline $21-26$ & $14.9 \%$ \\
\hline $27-32$ & $11.9 \%$ \\
\hline $33-38$ & $25.4 \%$ \\
\hline $39-44$ & $16.4 \%$ \\
\hline $45-50$ & $10.4 \%$ \\
\hline & \\
\hline & \\
\hline & \\
\hline & \\
\hline
\end{tabular}

informed that they were under no compulsion whatsoever to answer any of the questions. During the interview, before the more sensitive questions were asked, the client was once again given the choice to complete or terminate the interview.

\section{Objectives}

The general aim of this study was to identify the obstacles to condom usage by clients in Region B and to develop strategies to encourage effective condom usage.

The specific objectives of this study were to determine

- whether clinics are accessible to clients - since inaccessible clinics may have a negative impact on condom use.

- $\quad$ clients' perceptions with regard to primary health care workers' attitudes towards them as clients - as this may impact on willingness of clients to discuss sensitive sexual issues with the PHC worker.

- whether clients use condoms correctly and consistently.

- what patterns of condom use exists so that existing counseling programmes can be reevaluated and possibly improved. 
Research findings

\section{Profile of respondents}

The biographical information of the respondents are reflected in table 1 .

The biographical information of the respondents indicates a relatively low socio-economic status in terms of income.

\section{Problems related to condom usage}

The findings will be discussed in two sections: Firstly the problems related to service factors will be discussed and secondly problems that stem from the behaviour and attitudes of the client themselves.

\section{Factors related to service provision}

The following factors related to the service rendered to the client by the PHC clinic and staff with regards to condom use, were investigated

\section{- Staff's attitudes towards clients}

In the health care setting the attitude of staff towards the client is of the utmost importance. This is particu -larly true when things of a sensitive nature are dealt with. Regarding the issue of STI, it is obvious that the staff must evoke feelings of trust from the client and that the client must be at ease with the staff member. If the behaviour of the staff of the PHC clinics is negative, it might constitute an obstacle to effective con- and $7.2 \%$ that staff members were not helpful. The types of incidents that were identified here included where staff made the client feel uncomfortable or unimportant, were unhelpful, or failed to provide proper counseling.

What was encouraging is that a relationship of trust appears to exist between clinic staff and clients as respondents indicated that they perceive the staff as trustworthy. To the question "why they trust staff", $28.6 \%$ of the respondents indicated that it was because clinic staff were helpful, and $17.5 \%$ that they were trained.

Importantly, it also appears that the clinic staff generally understood what the respondents wanted of them with 69 of the 70 clients indicating this to be the case. However, it appears that it was more difficult for respondents to understand staff. While $63.8 \%$ of the respondents indicated that they never experienced any difficulties in understanding staff, $26.1 \%$ indicated that they generally had problems understanding staff. This is an important observation as it is crucial that the client understands the instructions of the PHC worker pertaining to health issues in order to ensure the successful treatment of the client.

It may be noted that clients generally have a positive perception of the service rendered by PHC clinics as well as of the staff's attitude and behaviour. Thus, it may be deduced that this dimension does not present major problems in establishing a positive condom-use culture in region B of the Free State, except perhaps that staff members may not always be understood.

\section{Table 2: Respondents' perceptions of clinic staff 's treatment of clients}

\begin{tabular}{|l|c|c|c|c|}
\hline \multicolumn{1}{|c|}{$\begin{array}{c}\text { Are clinic staff } \\
\text { members }\end{array}$} & Always & Sometimes & Never & N \\
\hline Friendly? & $93.8 \%$ & $4.6 \%$ & $1.5 \%$ & 65 \\
\hline Impolite? & $2.0 \%$ & $6.1 \%$ & $91.8 \%$ & 48 \\
\hline Helpful? & $92.7 \%$ & $3.6 \%$ & $3.6 \%$ & 55 \\
\hline
\end{tabular}

dom use.

Clients have a positive perception of the clinic staff and the treatment they receive from the PHC workers (see table 2). The overwhelming majority of respondents $(91.8 \%)$ indicated that the staff never treats them in an impolite manner. Only 4 respondents $(8.1 \%)$ indicated that staff members were impolite

\section{- Accessibility and proximity of primary health care clinics}

The accessibility of clinics was also investigated. If clinics are inaccessible (for whatever reason) it stands to reason that con- 
clients. However, in this study for most of the respondents, reaching the clinic poses no problems as was indicated by $82.8 \%$. The vast majority of the respondents $(85.7 \% ; \mathrm{N}=70)$ indicated that there were no costs involved in reaching the clinic.

In addition to being easy to reach, clinic hours also seem to suit the respondents of this study as indicated by $94.3 \%$. Only distribution. The overwhelming majority of respondents felt the clinic was the most appropriate place to obtain condoms.

\section{Most appropriate place for distribution}

According to Crichton (1997: 38) there are three main players in the distribution of condoms: the government, non-governmental organisations and commercial manufacturers (see table 3 ).

\section{Table 3: The channels of condom distribution (WHO, 1995:9)}

\begin{tabular}{|c|c|c|c|}
\hline Distribution channels & & Approach & Out lets \\
\hline Government & $\begin{array}{l}1 . \\
2 .\end{array}$ & $\begin{array}{l}\text { Family planning } \\
\text { Disease prevention }\end{array}$ & Clinics and hospitals \\
\hline $\begin{array}{c}\text { Non-governmental } \\
\text { organisations }\end{array}$ & $\begin{array}{l}\cdot \\
\cdot \\
\cdot\end{array}$ & $\begin{array}{l}\text { Targeted distribution } \\
\text { Disease prevention } \\
\text { Condom promotion }\end{array}$ & $\begin{array}{l}\text { Community based distribution } \\
\text { targeting high risk groups and } \\
\text { family planning }\end{array}$ \\
\hline 4 Commercial manufacturers & $\begin{array}{l}\text { a) } \\
\text { b) }\end{array}$ & $\begin{array}{l}\text { Profit making enterprise } \\
\text { Social marketing } \\
\text { programmes }\end{array}$ & $\begin{array}{l}\text { Access for both the general } \\
\text { public and target population }\end{array}$ \\
\hline
\end{tabular}

\section{Table 4: The most approriate place to obtain condoms}

\begin{tabular}{|l|c|c|}
\hline Place & Responses & $\%$ \\
\hline 1. Clinic & 59 & 88.1 \\
\hline 2. Post office & 1 & 1.5 \\
\hline 3. Public toilet & 1 & 1.5 \\
\hline 4. Café & 1 & 1.5 \\
\hline 5. Petrol station & 5 & 7.5 \\
\hline $\mathbf{N}$ & 67 & 100 \\
\hline
\end{tabular}

$5.7 \%$ of clients indicated that the clinic hours are inconvenient. The latter group indicated that the clinics are only open during business hours and that it is impossible for them to visit the clinic during those hours.

On the grounds of the above-mentioned findings, it may be concluded that problems with regard to transport to and the accessibility of clinics do not present major obstacles to clients attempting to obtain condoms. It appears that clinics are relatively accessible.

This ties in with the next factor - the most appropriate place for
The focus of this study is the condoms that are made available at clinics and that are provided by the government. As mentioned earlier, the respondents regard clinics as the most appropriate place to obtain condoms.

Although condoms are available free of charge at clinics, it has often been suggested that they should also be made available free of charge at other places, such as dance clubs and bars. In terms of the results in table 3 , however, it appears that respondents believe that the clinic is the best place to obtain condoms. 
In this study more than half of the respondents $(59 \%, \mathrm{~N}=64)$ indicated that they would not feel embarrassed to buy condoms at a shop. Forty-seven $(\mathrm{N}=64)$ of the respondents did not believe that condoms bought at a shop are of a better quality than those obtainable from the clinic; $44 \%$ of the respondents were, however, not sure about this issue.

\section{- Excessive demands on primary health care services}

A problem that became evident from the focus group discussions is the negative impact that heavy workloads have on condom programmes. It was argued that as a result of heavy workloads and understaffing in PHC clinics, it is often not possible to provide detailed counseling regarding condom usage It appears that the provision of information to the client with regard to condom use is not high on the priority list of the $\mathrm{PHC}$ worker.

The above state of affairs is unfortunate, as it is crucial that the correct use of condoms must be conveyed effectively and in positive terms to the client in order to encourage correct and consistent use. Moreover, in most cases demonstrations of the correct use of condoms are not included in the counseling process. The giving of the necessary verbal feedback and testing of the client to determine whether adequate reinforcement has taken place are processes that are seldom performed. Language differences may also create a problem because information is often conveyed to the client in a language other than his/her mother tongue

According to the participants of the focus group, raising awareness of effective condom use by the PHC worker in the client, is often absent. Therefore, an unconscious choice is forced on the client not to use condoms or may result in the incorrect use of condoms which renders them ineffective.

\section{- Socio-cultural convictions of the primary health care-worker and fear of stigmatisation}

PHC workers participating in the focus groups also mentioned the possibility that the socio-cultural convictions of the primary health care worker may contribute to a situation where he/she might be unwilling to make condoms freely available.

There is a possibility that some PHC workers who hold the belief that condoms encourage promiscuity are guilty of stigmatising clients who ask for condoms through their reactions or behaviour. In this way, they discourage condom use. PHC workers may also, due to their fear of being stigmatised by their community, be hesitant to make condoms freely available. and may even discourage their use. A local church council has for example, censured the staff of a particular PHC clinic in the region because they allegedly approve of and encourage promiscuity by encouraging the use of condoms and by making condoms available free of charge.
Members of the focus group stated that there is still a stigma attached to the use of condoms and that some moralists in the community believe that encouraging the use of condoms, encourages sexual promiscuity. This has an impact on the mindset of the PHC workers and thus ultimately on the condom usage of clients.

\section{- Attractiveness}

According to the PHC workers who participated in the focus group, condoms available at clinics, are unattractive in comparison with the condoms that are available in the market

In response to the increasing interest in condom use, commercial manufacturers have begun to manufacture condoms in a variety of sizes, shapes, textures and colours. PHC workers suggest that if various kinds of condoms, in terms of colour and improved packaging, are made available at clinics, it can possibly stimulate the clients' attention. and the item will "sell" itself. PHC workers also complained that packaging material is not available at clinics, and the client must bring his own paper or plastic bag for this purpose. This, they said, creates the impression of unprofessional service.

Focus group participants also mentioned a batch of particularly poor quality condoms once received: not only did the lubricant ooze from the packaging, but they also had an unpleasant odour and the packaging had a unattractive brown colour. One primary health care worker described the batch as "utterly repulsive" and questioned the quality of the product. In a study amongst primary health care workers in the Free State clinics by Crichton (1997: 84), as many as 30 per cent of the respondents $(\mathrm{N}=84)$ were dissatisfied with the condoms supplied to their clinics.

\section{Factors related to the client}

The first section touched on factors related to the PHC setting that may discourage the use of condoms. In this section factors related to the clients themselves such as: the nature of sexual relationships that clients develop with their partners; condom usage within these relationships and other genera issues regarding the use of condoms, are investigated.

\section{- The nature of sexual relationships}

A relatively high percentage of respondents had more than one sex partner during the previous month, which is possibly an explanation for the reported high incidence of sexually transmitted infections. Sixty per cent of respondents had only one sex partner during the preceding month, while the remaining $40 \%$ have had two or more sex partners. Twenty four per cent indicate having two partners, $7.7 \%$ had three partners and $7.7 \%$ four. These findings have to be interpreted in the light of the biographical information where $67 \%$ of the respondents are single, $17.6 \%$ are cohabiting and only $14.7 \%$ are in a marita (legal or traditional) relationships.

In terms of the nature of the reported sexual relationships re spondents were engaged in, $66.7 \%$ of the relationships were with the steady partner, but a significant proportion $(33.3 \%)$ 
with a "casual" partner with whom no steady relationship was established or a "new" partner. Of the respondents, 31 (49.2 $\%)$ indicated that they had used condoms during the previous month. while $32(50.8 \%)$ indicated that they did not use condoms.

\section{- Reasons for condom use or non-use and negotiating the issue}

In this section, the following issues were investigated:

- the reasons respondents give for using or not using condoms;

- who the person in the relationships was that wanted to use condoms;

- factors that prevent respondents from obtaining condoms;

- $\quad$ practices related to correct condom use and

- $\quad$ personal perceptions regarding condom use.

When reasons for condom usage were investigated the following became evident: $40 \%$ ( 10 of 25 respondents) indicated condoms because they trust their partners implies that condom usage may be associated with mistrust.

It may be deduced from the results in table 6 that more discussion about condom usage exists in steady relationships: $48,4 \%$ of respondents in steady relationships stated that they wanted to use condoms, while $41.9 \%$ of them stated that both partners wanted to use condoms. When "casual" relationships are involved, only 2 of the 11 respondents in the category "single casual partner" indicated that both wanted to (that is $18.2 \%$ ). Of the respondents, $72.7 \%$ who responded here indicated that they desired to use condoms. Therefore, it appears as if the encouragement to use condoms has to be accompanied by the encouragement to have a single sex partner in a steady relationship. It is in a steady relationship where it is likely that greater openness and discussion occurs between partners, and this appears to encourage the use of condoms.

\section{- Condom use}

According to Crichton (1997: 50) the correct use of condoms cannot be overemphasized as the correct use reduces the con-

\section{Table 5: Reasons offered why condoms were not used}

\begin{tabular}{|l|c|c|}
\hline \multicolumn{1}{|c|}{ Reason offered for non-use } & Frequency & $\%$ \\
\hline 1. Trust partner & 12 & 57.1 \\
\hline 2. Wants direct contact & 2 & 9.5 \\
\hline 3. Partner refuses & 3 & 14.3 \\
\hline 4. Ignorance (does not know how) & 2 & 9.5 \\
\hline 5. Wants to become pregnant & $\mathbf{1}$ & 4.8 \\
\hline 6. Not available & I & 4.8 \\
\hline N & $\mathbf{2 1}$ & $\mathbf{1 0 0}$ \\
\hline
\end{tabular}

that they use condoms as a means of preventing STI's and $16 \%$ (4 of 25 respondents) indicated that they used condoms because they did not trust their partners. Of the respondents, $44 \%$ indicated using condoms primarily for the purpose of preventing pregnancy.

According to the data presented in table 5, the most important reason offered by respondents why they do not use condoms, is that they trust their partner ( 12 out of $21 ; 57.1 \%$ ). It sometimes also happens that the partner refuses to use a condom ( 3 out of 21 respondents; $14.3 \%$ ). Moreover, some respondents stated that they wanted direct contact ( 2 out of $21 ; 9.5 \%$ ), and that they were unfamiliar with the use of condoms ( 2 out of 21 ; $9.5 \%$ ). The fact that 58 per cent indicated that they do not use dom's failure rate and consequently increases its protective qualities.

From the results presented in table 7 , it is deducted that the broad and simple principles of condom use are indeed being followed during sexual intercourse. However, the finer points are often neglected, for example, sexual contact takes place before the condom is placed over the penis; the penis is not always withdrawn while it is still erect, nor is the penis (and condom) consistently held tight at the base when it is withdrawn. This may explain why sexually transmitted infections are sometimes manifested. even when clients report that they do, in fact, use condoms. These findings confirm the earlier 


\section{Table 6: Responses to the question as to which partner in the relationship wanted to use}

\begin{tabular}{|c|c|c|c|c|c|}
\hline \multicolumn{2}{|c|}{ Type of partner } & \multirow{2}{*}{\begin{tabular}{|c|} 
Respondent \\
wanted to
\end{tabular}} & \multirow{2}{*}{$\begin{array}{c}\begin{array}{l}\text { Partner } \\
\text { wanted to }\end{array} \\
9.7 \%\end{array}$} & \multirow{2}{*}{$\begin{array}{r}\begin{array}{l}\text { Both } \\
\text { Wanted to }\end{array} \\
41.9 \%\end{array}$} & \multirow{2}{*}{$\begin{array}{l}\mathbf{N} \\
31\end{array}$} \\
\hline 1. & $\begin{array}{l}\text { Single partner } \\
\text { (long term) }\end{array}$ & & & & \\
\hline 2. & $\begin{array}{l}\text { "Casual" } \\
\text { single partner }\end{array}$ & $72.7 \%$ & $9.1 \%$ & $18.2 \%$ & 11 \\
\hline & $\begin{array}{l}\text { "Casual" } \\
\text { tners }\end{array}$ & $100 \%$ & & & 4 \\
\hline \multicolumn{3}{|c|}{3 partners } & & & 1 \\
\hline & partner & $100 \%$ & & & 3 \\
\hline \multicolumn{5}{|l|}{$\mathrm{N}$} & 50 \\
\hline
\end{tabular}

statement that counselling related to sexual practices and the correct use of condoms do not always receive the necessary attention in primary health care clinics.

\section{- Personal perceptions related to condom use}

Condoms are often perceived negatively, being associated with "prostitution, ineffectiveness or unreliability, failures due to breakages and the suspicion of STD or HIV infection of people using condoms." (Crichton, 1997: 46) This study however revealed a more positive perception as is indicated in table 8 .

The results reported in table 8 indicate a general acceptance of the use of condoms among respondents. For example, 79.7\% indicated that they would not feel offended if theit partners insisted on using a condom. Of the respondents, $79.4 \%$ indicated if they were to have sexual intercourse with someone they did not know, they would suggest that a condom be used. This response could be a result of increased media coverage concerning the important of condom usage, it must, however, also be kept in mind that this overwhelmingly positive response could be due to the social desirability effect, which refers to the need of an individual to impress another by agreeing with them. The respondents may have wanted to impress the PHC workers who promote the use of condoms and who are in favour of condoms.

\section{Concluding comments}

It was postulated initially in this study that ineffective condom use might be related to a variety of factors. This study, how- ever, showed that the accessibility and proximity of clinics in the area of study were not significant problems to respondents who were involved in the study. It also seems that PHC workers attitudes and behaviour towards clients in the specific area were not factors that discouraged clients from using condoms as, in general, respondents had a positive perception of clinic staff's behaviour towards them and showed a high level trust in them.

The biggest problem identified by this study is that a significant percentage of clients did not use condoms consistently in the correct way. The data collected confirms that although clients do not have difficulties in obtaining condoms, they are often used incorrectly and clients do not consistently follow the correct procedures so that safe sexual intercourse are always ensured.

Given that a high percentage of the investigated group had more than one sex partner in the preceding month. it is of importance not only that condoms are made available free of charge, but also that the availability of condoms has to be accompanied by an effective and thorough counselling pro gramme. It therefore a concern that $\mathrm{PHC}$ workers reported that as a result of enormous demands made on them, (in terms of course attendance and client overload), they spend too little time in clinics and with their patients. In fact many of the PHC workers who were requested to complete the questionnaire with their clients for the purposes of this study, complained that they did not have enough time. This is disconcerting, since most of the questions that were posed in the client questinnaire, were questions that had to be dealt with any client presenting with a STI. 


\section{Recommendations}

The first recommendation is that the workload of the PHC has to be specifically tasked to perform this kind of work on a full-time basis.

In addition to the above. the authors recommend that any condom education programme should not only provide counselling related to the effective and correct use of condoms, but

\section{Table 7: Practices regarding condom use}

\begin{tabular}{|c|c|c|c|c|c|c|}
\hline & Condom use & Always & Generally & $\begin{array}{l}\text { Some- } \\
\text { Times }\end{array}$ & Never & $\mathbf{N}$ \\
\hline 1. & $\begin{array}{l}\text { Penis erect when } \\
\text { condom is placed } \\
\text { over organ }\end{array}$ & $79.4 \%$ & $14.7 \%$ & $2.9 \%$ & $2.9 \%$ & 33 \\
\hline 2. & $\begin{array}{l}\text { Condom placed } \\
\text { over penis before } \\
\text { contact with } \\
\text { mouth/anus/vulva }\end{array}$ & $59.4 \%$ & $18.8 \%$ & $6.3 \%$ & $15.6 \%$ & 32 \\
\hline 3. & $\begin{array}{l}\text { All air removed } \\
\text { from front portion } \\
\text { of condom once } \\
\text { placed over penis }\end{array}$ & $62.5 \%$ & $9.4 \%$ & $18.8 \%$ & $9.4 \%$ & 32 \\
\hline 4. & $\begin{array}{l}\text { Condom rolled } \\
\text { down entirely to } \\
\text { the base of the } \\
\text { penis }\end{array}$ & $79.4 \%$ & $11.8 \%$ & $0 \%$ & $8.8 \%$ & 34 \\
\hline 5. & $\begin{array}{l}\text { After intercourse } \\
\text { penis is removed } \\
\text { while still erect }\end{array}$ & $56.3 \%$ & $15.6 \%$ & $9.4 \%$ & $18.8 \%$ & 32 \\
\hline 6. & $\begin{array}{l}\text { When the penis is } \\
\text { withdrawn, the } \\
\text { condom is held } \\
\text { tight at the base }\end{array}$ & $53.1 \%$ & $25 \%$ & $3.1 \%$ & $18.8 \%$ & 32 \\
\hline 7. & $\begin{array}{l}\text { Condom tied in } \\
\text { knot and thrown } \\
\text { away after use }\end{array}$ & $56.7 \%$ & $10 \%$ & $10 \%$ & $23.3 \%$ & 30 \\
\hline
\end{tabular}

worker and the patient load that clinics have to carry be investigated or re-investigated. Not only that condom education be improved but also to enable to $\mathrm{PHC}$ worker to give each client the attention they deserve/need.

Members of the focus group recommended that a specific person, who does not necessarily have to be a member of the trained nursing staff, but who has an insider's knowledge of the community and the culture and who speak their language, should also encourage monogamous, steady relationships. Apart from reducing ones risk of acquiring a STI, it appears that more discussion related to condom use is elicited between sex partners who find themselves in such a relationship. Programmes should thus also focus on relationship issues. In light of the raging HIV epidemic, the correct use of condom has become a matter of life and death to many South Africans. The government, through the PHC sector remains one of the 


\begin{tabular}{|c|c|c|c|c|c|}
\hline \multicolumn{2}{|r|}{ Perception } & Uncertain & Yes & No & $\mathbf{N}$ \\
\hline 1. & $\begin{array}{l}\text { I will feel offended if my sex } \\
\text { partner wants to use a condom }\end{array}$ & $7.8 \%$ & $12.5 \%$ & $79.7 \%$ & 64 \\
\hline 2. & $\begin{array}{l}\text { If I plan to have sex with a } \\
\text { person whom I do not know, I } \\
\text { will suggest that we use a } \\
\text { condom }\end{array}$ & $11.1 \%$ & $79.4 \%$ & $9.5 \%$ & 63 \\
\hline 3. & $\begin{array}{l}\text { I will know how to suggest the } \\
\text { use of a condom before sexual } \\
\text { intercourse }\end{array}$ & $11.3 \%$ & $69.4 \%$ & $19.4 \%$ & 62 \\
\hline 4. & $\begin{array}{l}\text { Even if I use another family- } \\
\text { planning method, I will also use } \\
\text { a condom }\end{array}$ & $7.8 \%$ & $73.4 \%$ & $18.8 \%$ & 64 \\
\hline
\end{tabular}

most important distributors of condoms. It is crucial that at this point of contact, where a trained person is available, the correct and consistent use of condoms be encouraged, explained and reinforced and in this way prevent a disaster.

\section{References}

CRICHTON, AM 1997. Condom programming in Free State Health Care Clinics. Unpublished Masters Degree Dissertation. Bloemfontein: University of the Orange Free State.

DEPARTMENT OF HEALTH 1998. South Africa demographic and health survey 1998 (preliminary report). RSA: DOH.

JOFFE, A 1993. Adolescents and Condom Use. AIDC (14): 70 -1016 .

KEY,SW; DE NOON, DJ \& BOYLES, S 1997. Sexually Transmitted Infections: the iceberg under South Africa's AIDS epidemic. Aids Weekly Plus, (December, 22-29): 12.

PESA, JA; SYRE, TR \& FU, Q 1999. Condom use and problem behaviour among sexually active adolescents. Journal of Health Education 30(2): 120-124.

SANKAR, NM \& KARIM, QA 1991. Factors influencing condom use amongst African teenagers. Urbanisation and Health (10): 22-24.

THE HEALTHSYSTEMS TRUST AND THE DEPARTMENT OF HEALTH (South Africa) 1996. Health Care in the Free State. Durban: The Health Systems Trust and the Department of Health.
WARREN, M 1997. Condom use in South Africa: Fact and fantasies. AIDS Scan 9(3): 22-24.

WORLD HEALTH ORGANISATION 1995. Specifications and Guidelines For Condom Procurement.

\section{Acknowledgments}

The authors wish to acknowledge the contributions made to this publication by the following primary health care workers who participated in the research project: Croucamp S, Dekker S, Le Roux E, Memane N, Stander M, Strauss S, Thile E, Van Rensburg SJ, Wilson E. 